\title{
Viral Enteritis in Cattle: To Well Known Viruses and Beyond
}

\author{
Matías Castells *(D) and Rodney Colina * \\ Centro Universitario Regional Litoral Norte, Laboratorio de Virología Molecular, Universidad de la República, \\ Salto 50000, Uruguay \\ * Correspondence: matiascastellsbauer@gmail.com (M.C.); rodneycolina1@gmail.com (R.C.); \\ Tel.: +598-4734-2924 (M.C. \& R.C.)
}

\begin{abstract}
Livestock products supply about 13 percent of energy and 28 percent of protein in diets consumed worldwide. Diarrhea is a leading cause of sickness and death of beef and dairy calves in their first month of life and also affecting adult cattle, resulting in large economic losses and a negative impact on animal welfare. Despite the usual multifactorial origin, viruses are generally involved, being among the most important causes of diarrhea. There are several viruses that have been confirmed as etiological agents (i.e., rotavirus and coronavirus), and some viruses that are not yet confirmed as etiological agents. This review summarizes the viruses that have been detected in the enteric tract of cattle and tries to deepen and gather knowledge about them.
\end{abstract}

Keywords: rotavirus; coronavirus; norovirus; torovirus; astrovirus; nebovirus; pestivirus; kobuvirus; bocaparvovirus; enterovirus; orthobunyavirus; diarrhea; cattle

check for

updates

Citation: Castells, M.; Colina, R. Viral Enteritis in Cattle: To Well Known Viruses and Beyond. Microbiol. Res. 2021, 12, 663-682. https://doi.org/10.3390/microbiolres 12030048

Academic Editor: Chao-Nan Lin

Received: 2 May 2021

Accepted: 27 July 2021

Published: 12 August 2021

Publisher's Note: MDPI stays neutral with regard to jurisdictional claims in published maps and institutional affiliations.

Copyright: (c) 2021 by the authors. Licensee MDPI, Basel, Switzerland. This article is an open access article distributed under the terms and conditions of the Creative Commons Attribution (CC BY) license (https:// creativecommons.org/licenses/by/ $4.0 /)$.

\section{Introduction}

Cattle production constitutes an important component of the agricultural economy of many countries, a contribution that goes beyond direct food production. Furthermore, livestock are closely linked to the social and cultural lives of several million farmers [1] Livestock products supply about 13 percent of energy and 28 percent of protein in diets consumed worldwide [2]. To meet the projected demand for animal products, the industry must streamline production and advance capacity to prevent, detect, diagnose, and treat animal diseases [2].

The cost of gastrointestinal disease per calf per year (including cost of prevention) was estimated to be 33.46 U.S. dollars, being the cause with the highest cost in dairy calves, while the cost of the same disease per cow per year (including cost of prevention) was estimated to be 11.13 U.S. dollars, being the third cause with major cost in adult dairy cattle [3].

\section{Diarrhea in Cattle}

Diarrhea is usually a multifactorial disease related to a combination of host, pathogen, management, and environmental factors. The cause of an outbreak of diarrhea is rarely known, and the most important reason for poor diagnosis is that little is known about the large number of microorganisms that have been shown, or claimed, to be causal [4]. Increased mortality and morbidity are often due to the presence of more than one pathogen [5]. Intestinal pathogens produce diarrhea via several mechanisms that include: villous atrophy, malabsorption, osmotic diarrhea, secretory diarrhea, and inflammatory diarrhea [6,7].

Prevention and control of diarrhea should be based on a good understanding of the complexities of the disease, such as multiple pathogens, coinfection, environmental, nutritional, and management factors. Among the non-viral pathogens, the most prevalent worldwide are Escherichia coli, Salmonella enterica, and Cryptosporidium parvum. Although there is no specific treatment for the latter, antibiotics can be used in the case of a bacterial infection. The main characteristics of viral agents are described in this review, but the role that non-viral agents play in diarrhea should not be underestimated. 
To determine the causality of viruses is sometimes difficult due to several factors that can hinder this determination. Regarding the pathological anatomy, some viral infections damage may not be obvious, but infected cells may carry out their functions less effectively, and clinical signs may reflect this. The virus may cause a loss in specialized functions of cells required not so much for their own survival but for systemic homeostasis [8]. In addition, viruses can be detected several hours before the onset of clinical symptoms, during the presence of diarrhea, and several weeks after the feces return to normal, and this long shedding may interfere with the results obtained in case-control studies [9]. Depending on various factors, viruses can also infect asymptomatically in some animals, which increases the inaccuracies of determining the causality of viruses in the disease [10]; it is worthy to note that asymptomatic calves can shed viruses as symptomatic calves do [10]. In the same line, some viruses do not seem to be pathogenic, but in coinfection with other viruses, their infectious capacity can be increased [11]. Moreover, some enteric viruses also have extra-intestinal tropism, as occurs with bovine coronavirus [12]. Then, viruses causing respiratory disease can be excreted in feces, interfering with the observations that can be made regarding the virus excretion and diarrhea.

The persistence of this significant problem in the field may be attributed, in part, to the multifactorial nature of the disease. In addition, genetic diversity, continuous evolution, emergence, and/or environmental ubiquity of viruses are factors that hinder effective control of the disease. Therefore, the genetic evolution of viral pathogens should be kept in mind and monitored with regular genomic sequence updates, and emerging viruses should be regularly monitored [13].

\subsection{Virus and the Disease}

As stated above, viral infection is not synonymous with disease, as many viral infections are subclinical, whereas others result in diseases of varying severity and clinical signs, which is commonly called the iceberg concept of viral infection and diseases [14].

Among other factors, the virulence of the infecting virus and the susceptibility of the host are the most relevant in determining the course of infection and the appearance or not of the disease [14].

Viruses differ greatly in their virulence, but even in a population infected by a particular virus strain, there are usually striking differences in the outcome of infection between individual animals. In addition, there is much variation among viruses of the same species. Virus strain differences may be quantitative, involving the rate and yield of virus replication, lethal dose, infectious dose, the number of cells infected in a given organ, or they may be qualitative, involving organ or tissue tropism, extent of host-cell damage, mode and efficacy of spread in the body, and character of the disease they induce [14].

\subsection{Neonatal Calf Diarrhea Syndrome}

The health status of calves in the first days of life is essential for their survival and subsequent development, so the diseases that affect calves in those days are an important cause of economic losses worldwide [15-17]. Diarrhea is a leading cause of sickness and death of beef and dairy calves in their first month of life [18-24] and has a negative impact on animal welfare [15-17]. Overall, beef calf mortality from diarrhea should be about $1 \%$, and in dairy calves, diarrhea accounts for about $5 \%$ of total mortality from live birth to weaning [6]. Economic losses are not only due to mortality but also due to the cost of treatment and management [25]. In addition, diarrhea has long-term effects on productive and reproductive performance, such as reduction in milk production, reduction in the average daily gain of weight, and the requirement of more inseminations to become pregnant [26].

\subsection{Diarrhea in Adult Cattle}

Epizootic diarrhea frequently occurs during the colder months in dairy and beef adult cattle $[27,28]$, resulting in large economic losses from marked reductions in milk production 
that may not return to normal for several months in dairy cattle [28,29], and weight loss in beef cattle. The disease spreads rapidly among adult cattle within an affected herd leading to very high morbidity (50-100\%) but a low mortality rate (1-2\%) [28-30], but it is not usually spread among calves [29,31]. Diarrhea lasts from a few days to several weeks [27,29], and is generally characterized by an acute onset of dark diarrhea with or without blood, and can be accompanied by anorexia, respiratory symptoms (dyspnea, nasolacrimal discharge, and cough), and high body temperature in most severe cases [28-30]. Young adult animals, especially pregnant, recently calved, or lactating cows, are the most severely affected, but bulls, steers, and beef cattle are also affected, as well as feedlot cattle [27,30]. The most common viral etiologies of diarrhea in adult cattle are coronavirus and torovirus, and the disease is called winter dysentery in these cases, but diarrhea can also be observed in outbreaks caused by an orthobunyavirus.

\section{An Iconic Case: Rinderpest}

Rinderpest, also known as cattle plague, was discovered in 1902 and declared eradicated in 2011 [14,32], being the second virus that achieved this status after smallpox. Rinderpest was one of the most or probably the most dreadful animal disease with severe impacts on livelihoods, with high morbidity rates and mortality rates of $80 \%$ to $90 \%$ in naïve populations [32-34]. In sub-Saharan Africa, when introduced in 1889, killed more than 90\% of the cattle and oxen there, leading to devastating famines, and the events are considered Africa's worst natural disaster [33,34]. The economic losses and then the benefits of the eradication have been both estimated in billions of dollars $[33,35,36]$. Rinderpest was characterized by necrosis and erosions throughout the digestive tract and usually started with fever, but was evident by severe diarrhea and dysentery, followed by dehydration and wasting, and death 6 to 12 days after symptoms appeared [33,34,36]. Other symptoms observed were oozing sores in the mouths and nasal and ocular discharges [33,36]. The animals that survived became immune for life $[33,36]$. Rinderpest eradication is a milestone for virologists.

\section{Rotavirus}

In 1969, it was confirmed for the first time that a "reo-type virus" was the cause of diarrhea in calves [37] and years later named rotavirus because electron microscopy had a similar appearance to a wheel (rota in Latin). Since the discovery, rotaviruses have been considered the main causal agent of neonatal calf diarrhea [38], inflicting serious losses on the livestock sector [39].

Some of the structural characteristics are: they are icosahedral particles of 100 nanometers (nm) in diameter (including spikes), they are non-enveloped viruses with a three-layer capsid (Table 1), and inside the capsid, they have all the enzymes necessary for the production of messenger RNA (mRNA). Shared genomic characteristics are: they consist of 11 segments of double-stranded RNA (dsRNA) (Table 1), these RNA segments are non-infectious, each RNA segment encodes at least one protein, and RNA segments from different viruses can be genetically reassorted with a high frequency during coinfection of a cell. Finally, the replicative characteristics are: culture is facilitated by proteases such as trypsin or pancreatin, replication occurs in the cytoplasm, they form inclusion bodies, morphogenesis involves transient enveloped particles, and viral particles are released by cell lysis or by non-classical vesicular transport in polarized epithelial cells [40].

Taxonomically, rotaviruses, according to the International Committee for the Taxonomy of Viruses (ICTV), are currently classified as: Riboviria > Orthornavirae > Duplornaviricota $>$ Resentoviricetes > Reovirales > Reoviridae > Sedoreovirinae > Rotavirus. Rotaviruses are serologically classified into 10 different groups or species, named Rotavirus $A-J$. Rotavirus $A$, Rotavirus $B$, and Rotavirus $C$ have been detected in cattle, but the most widely dispersed and important are the Rotavirus A (RVA); this review is focused on this species. Furthermore, RVA is classified antigenically into serotypes (based on neutralizing epitopes of the VP4 and VP7 viral proteins) and genetically into genotypes, with certain differences between 
the classification of serotypes and genotypes in VP4 [40]. So far, there are 35 VP4 genotypes (P1-35) and 27 VP7 genotypes (G1-27) within the RVA group [41], of which 11 P types (P1, P3, P5, P6, P7, P11, P14, P17, P21, P29 and P33) and 12 G types (G1, G2, G3, G5, G6, G8, G10, G11, G15, G17, G21, and G24) have been identified in cattle. However, G6, G8, and G10 genotypes associated with P1, P5, and P11 are the most commonly found in bovines [42]. Classification within RVA is commonly performed using a binary system with the different types of VP7 and VP4, GXP[Y], where X is the G-type and Y is the P-type. VP4 and VP7 genotypes are determined by sequence analysis, while serotypes are determined by the reactivity of individual or recombinant strains selected with polyclonal or monoclonal antisera. For VP7, a correlation between genotype and serotype has been established. The lack of serum or monoclonal antibodies for different types of VP4 available has hampered the classification of VP4 into serotypes. However, a variable region, VP8*, extending from amino acid (aa) 71 to 204 of VP4, may define specific P-type epitopes [40]. Moreover, there is a broader classification based on the nucleotide sequence, in which for each of the 11 segments VP7-VP4-VP6-VP1-VP2-VP3-NSP1-NSP2-NSP3-NSP4-NSP5/6, a particular genotype is assigned using the abbreviations Gx-P[x]-Ix-Rx-Cx-Mx-Ax-Nx-Tx-Ex-Hx (where $x$ corresponds to numbers starting from 1), respectively [43].

The disease is generally seen in young calves $2-8$ weeks of age, and susceptibility decreases as age advances. In neonates, the infection has a very short incubation period, manifesting as profuse diarrhea and severe dehydration. Diarrhea occurs primarily due to decreased absorption efficiency of enterocytes due to virus infection, and the severity can range from an asymptomatic or subclinical condition to severe enteritis. Furthermore, concurrent infection with secondary pathogens can increase the severity of the disease [39].

Transmission is generally by the fecal-oral route, and they are highly contagious; a low infectious dose of cell culture is sufficient to cause disease in a fully susceptible host. In addition, they are very stable in the environment and are excreted in large quantities in the feces, further increasing the possibility of transmission [40].

The current strategy to control the disease in cattle is based on the vaccination of cows during the last third of gestation to protect calves by transferring passive maternal antibodies through the ingestion of colostrum [44]. Although vaccines seem not to be effective in preventing RVA infection, they significantly reduce morbidity, the severity of diarrhea, and mortality related to RVA [44,45].

Phylogenetic studies of circulating RVAs in cattle contribute to a better understanding of the epidemiology of this pathogen, which translates into important information to evaluate the need to update vaccine strains and add complete data to elucidate the mechanisms of evolution of the virus [46].

Table 1. Main characteristics of the viruses reviewed.

\begin{tabular}{cccc}
\hline Virus Genus & Genome & Envelope & Virion Diameter (nm) \\
\hline Rotavirus & dsRNA segmented & No & 100 \\
Coronavirus & ssRNA (+) & Yes & $65-210$ \\
Norovirus & ssRNA (+) & No & $27-35$ \\
Torovirus & ssRNA (+) & Yes & $120-140$ \\
Astrovirus & ssRNA (+) & No & 28 \\
Nebovirus & ssRNA (+) & No & 33 \\
Pestivirus & ssRNA (+) & Yes & $40-60$ \\
Kobuvirus & ssRNA (+) & No & 30 \\
Bocaparvovirus & ssDNA & No & 30 \\
Enterovirus & ssRNA (+) & No & $30-32$ \\
Orthobunyavirus & ssRNA $(-)$ segmented & Yes & 100 \\
\hline
\end{tabular}

\section{Coronavirus}

The first report of bovine coronavirus (BCoV) was in 1971, during a trial of an oral rotavirus vaccine; coronavirus-like particles were found in the feces of a rotavirus-negative calf $[47,48]$. 
BCoVs are pleomorphic enveloped viruses with a diameter between 65 and $210 \mathrm{~nm}$ (Table 1). They are covered by a double layer of short (hemagglutinin esterase, HE) and long (spike, S) surface projections, which are involved in binding to cell receptors and are therefore important for immunity and vaccines [12]. The other two important structural proteins are the nucleocapsid protein $(\mathrm{N})$ and the integral membrane glycoprotein $(\mathrm{M})$. The genome consists of a positive-polarity single-stranded RNA of 27-30 kilobases $(\mathrm{kb})$ in size and is organized into seven regions that contain one or more open reading frames (ORF) (Table 1). These regions are separated by sites that contain the signal for the transcription of subgenomic mRNAs. Toward the $5^{\prime}$ end of the genome, non-structural proteins are encoded, including viral RNA polymerase, while toward the $3^{\prime}$ end, the order of structural proteins is $5^{\prime}$-HE-S-M-N-3' [28]. Like cellular mRNAs, it has a cap at the $5^{\prime}$ end and a poly-A tail at the $3^{\prime}$ end [49].

Currently, the taxonomic classification for $\mathrm{BCoV}$, according to the ICTV is: Riboviria Orthornavirae $>$ Pisuviricota $>$ Pisoniviricetes $>$ Nidovirales $>$ Cornidovirineae $>$ Coronaviridae $>$ Orthocoronavirinae > Betacoronavirus $>$ Embecovirus $>$ Betacoronavirus 1. The Betacoronavirus 1 species contains viruses that affect different hosts (animals and human) species; some members of this species are the human coronavirus OC43, the equine coronavirus, the porcine hemagglutinating encephalomyelitis virus, and $\mathrm{BCoV}$ itself. In addition, other important members of the Betacoronavirus genus are the coronavirus associated with severe acute respiratory syndrome (SARS)-CoV, the Middle East respiratory syndrome (MERS)$\mathrm{CoV}$, and the recently described and causing the COVID-19 pandemic, SARS-CoV-2. Until now, all isolates of $\mathrm{BCoV}$ belong to the same serotype with minor antigenic variations [28].

Currently, $\mathrm{BCoV}$ is widely recognized as one of the main causative agents of neonatal diarrhea in calves. In addition, it is considered the second-largest pathogen that causes deaths in calves, demonstrating the great severity of the disease caused [5]. In addition to neonatal diarrhea, it can cause respiratory infections and winter dysentery in adult cattle $[5,12]$. The virus multiplies in the cells of the intestinal crypts, decreasing the digestive and absorption capacity leading to diarrhea, with loss of water and electrolytes. In severe infections, diarrhea can cause dehydration, acidosis, and hypoglycemia, and death can occur due to acute shock and heart failure. The severity of enteritis varies both with the age and immune status of the calf as well as the infectious dose and strain of virus, developing more rapidly and more severe diarrhea in calves less than three months old, typically affecting calves between one and two weeks of age [28].

Transmission can be through both fecal-oral and respiratory routes and occurs mainly in the winter months. Furthermore, coronaviruses have been described as being capable of being stable and infectious for weeks in different types of environmental matrices, including water [50,51].

The current strategy to control the disease in cattle is based on vaccinating pregnant cows to protect calves by transferring passive maternal antibodies through ingestion of colostrum [52] and seems to be effective in preventing BCoV infection [53].

\section{Norovirus}

Bovine noroviruses (BoNoV) were first described in 1978 together with bovine astrovirus (BoAstV) and bovine nebovirus (BoNeV) in stool samples from diarrheic calves [54]. Although they are studied to a lesser extent than rotavirus and coronavirus, several studies confirmed that BoNoVs are widely present in cases of diarrhea in cattle from different countries, ranging from $3 \%$ to more than $60 \%$ [55-60]. In some countries, BoNoV can be the most prevalent enteric pathogen detected in cattle [60,61]. Furthermore, serological studies indicate that circulation and exposure to this virus are very high, detecting antibodies against BoNoV in almost $100 \%$ of the samples studied [56].

BoNoVs are non-enveloped viruses of 27 to $35 \mathrm{~nm}$ in diameter (Table 1), with a capsid of icosahedral symmetry with 180 molecules of the capsid protein organized into 90 dimers and whose surface shows 32 cup-shaped depressions and protruding arches (calici derived from the Latin word calyx, meaning chalice or cup) $[62,63]$. The genome is a single-stranded 
RNA of the positive polarity of approximately $7.5 \mathrm{~kb}$ and contains 3 ORFs [63] (Table 1). The $5^{\prime}$ end is linked to a viral protein called VPg, it does not have a ribosome entry site or cap, and it is assumed that VPg interacts with the components of the translational machinery, initiating the translation of viral RNA $[64,65]$. The $3^{\prime}$ end contains a poly-A tail. ORF1 (located toward the $5^{\prime}$ end of the RNA) codes for at least six non-structural proteins (p48, NTPase, p22, VPg, 3CLPro, and RdRp), ORF2 for VP1 and ORF3 for VP2 [63].

BoNoVs are classified within the genus Norovirus of the Caliciviridae family. The complete ICTV classification is: Riboviria > Orthornavirae > Pisuviricota > Pisoniviricetes > Picornavirales > Caliciviridae > Norovirus. BoNoVs are classified within genogroup III (GIII). There have been recognized three genotypes within GIII, namely GIII.1, GIII.2, and GIII.3, being GIII.1 and GIII.2 associated with BoNoV, and GIII.3 to ovine norovirus. In addition, several studies have demonstrated the circulation of recombinant strains, with the recombination breakpoint within the ORF1-ORF2 junction genomic region [66]. Recently, the emergence of a new genotype was described [60,67].

The genotypes GIII.1 and GIII.2, formerly referred to as Jena virus and Newbury-2 virus, respectively, have been deeply studied, and both genotypes showed to be diarrheagenic when inoculated experimentally into calves $[9,54,68,69]$. Under such circumstances, BoNoV GIII.1 induced lesions in the small intestine, including villus atrophy with loss and attenuation of the villus epithelium, and expression of viral capsid antigen was demonstrated by immunohistochemistry in the enterocytes [68]. Calves inoculated with BoNoV GIII.2 showed lesions in the small intestine, including hemorrhagic foci and shortening and thickening of the villi, although viral particles were not observed in cells by electron microscopy and viral antigen was not observed by immunofluorescence in the small intestine of infected calves [54]; in a recent study, no significant intestinal lesions in the infected calves were observed [69].

Transmission of BoNoV is not well understood, but for human noroviruses, transmission is mainly the fecal-oral route, and it is also suggested that another natural route of infection could be the respiratory tract through aerosol particles in vomit $[63,70]$. Caliciviruses are characterized by their high stability in the environment and resistance to inactivation [71-73]. In addition, low infectious doses, as well as its great diversity of strains, increase the risk of infection [63].

\section{Torovirus}

Bovine toroviruses (BToV) were detected for the first time in 1979 [74] in an establishment near the city of Breda in the state of Iowa, United States; hence, they were initially called Breda virus. The name torovirus comes from the Latin torus because the shape of the nucleocapsid is elongated tubular with helical symmetry and can bend, giving it the shape of a biconcave or kidney-shaped disk; viral particles have a peplomeric envelope that contains this nucleocapsid [75].

The genome is composed of a single-stranded RNA molecule of positive polarity and is 28,475 nucleotides long [76] (Table 1). It contains two overlapping ORFs, ORF1a, and ORF1b, that encode the proteins involved in replication, such as a serine protease, a cysteine protease, an adenosine diphosphate-ribose 1"-phosphatase (ADRP) domain, several hydrophobic domains that are typical of the replicase of nidoviruses, polymerase and helicase domains (in ORF1b), as well as sequences involved in a ribosomal frameshift, including the conserved slippery sequence UUUAAAC [76]. The structural proteins $S$ (peplomers), $\mathrm{M}$ (envelope), HE (hemagglutinin esterase), and $\mathrm{N}$ (nucleocapsid) are encoded toward the $3^{\prime}$ end $[76,77]$. At both ends $\left(5^{\prime}\right.$ and $\left.3^{\prime}\right)$, flanking the coding region, the genome contains two non-coding regions [76].

Initially, they were called the Breda virus and were grouped into a new family called Toroviridae according to the morphology and structure of the virion [75]. In 1992, toroviruses were reclassified as a new genus within the Coronaviridae family [78], but then in 2003, this family was divided into two subfamilies: Coronavirinae and Torovirinae [79]. Then, the BToVs were reclassified again, becoming part of the Torovirus genus of the Torovirinae 
subfamily, within the Coronaviridae family. However, the current classification by ICTV is: Riboviria > Orthornavirae > Pisuviricota > Pisoniviricetes > Nidovirales > Tornidovirineae , Tobaniviridae $>$ Torovirinae $>$ Torovirus $>$ Renitovirus $>$ Bovine torovirus.

Regarding the disease, BToVs have been described as enteric pathogens that cause mild to profuse diarrhea in calves in their first months of life [80], generating life risk in these animals [75]. In addition, they can affect adult cattle with clinical signs similar to winter dysentery caused by $\mathrm{BCoV}$; these signs are watery diarrhea and anorexia (which lead to weight loss), and in the case of dairy cows, there is a decrease in milk production [29]. Due to the clinical signs are similar to those caused by $\mathrm{BCoV}$ infections, it has been suggested that $\mathrm{BToV}$ may have been misdiagnosed as $\mathrm{BCoV}$ infection by clinical investigations [29]. The pathogenicity is mainly due to enteritis, but like coronaviruses, BToV can also affect the respiratory tract causing significant losses $[29,81]$. At the macroscopic level, thinness in the intestinal wall can be observed, while histologically, fusion and atrophy of the villi and epithelial desquamation are observed from the middle jejunum to the lower small intestine, in addition to areas of necrosis in the large intestine [82]. There is infection and necrosis of the villi and crypt enterocytes in the small intestine $[11,74]$ that appears to be unique to BToV; other viruses infect villus cells but not crypt cells, or vice versa [83]. Virions are most often observed in multiple, large autophagolysosomes [84].

$\mathrm{BToV}$ can be detected in fecal samples from a few hours before the onset of clinical symptoms, during the presence of diarrhea, and up to several days after the feces return to normal, and can also be detected in nasal swabs at the same time that the enteric shedding occurs [81]. This long shedding, together with the asymptomatic infection in some animals, may interfere with the results obtained in case-control studies. The transmission is mainly through the fecal-oral route, although they can also be transmitted through the respiratory route [85].

\section{Astrovirus}

As previously mentioned, BoAstV was first described in 1978 together with BoNoV and $\mathrm{BoNeV}$ in stool samples from diarrheic calves [54]. The BoAstV outer edges have $28 \mathrm{~nm}$ of diameter, and their surface structure shows some particles with a six-pointed star pattern [54] (Table 1), so the name astrovirus was bestowed (from the Greek astron, meaning star).

Astroviruses (AstV) have a single-stranded positive-sense RNA genome (Table 1). Regarding the organization of the genome, its length varies between 6253 and 6317 nucleotides, similar to other AstV with three overlapping ORFs that code for non-structural and capsid proteins [86]. ORF1a encodes a protease, nsp1a, and has a conserved "slippery heptameric" sequence near the $3^{\prime}$ end $\left(5^{\prime}\right.$-AAAAAAC- $\left.3^{\prime}\right)$, which is responsible for inducing a shift of ribosomal frameworks during translation to generate nsp1ab polyprotein [86]. ORF1a and ORF1b overlap in a region between 102 and 147 nucleotides in length. ORF1b has a -1 reading frame relative to ORF1a and encodes an RNA-dependent RNA polymerase. When taken together, ORF1a and ORF1b encode an nsp1ab polyprotein then cleaved by the viral protease to become active non-structural proteins. Finally, ORF2 is between 2280 and 2319 nucleotides in length and encodes structural proteins in the same reading frame as ORF1a [86].

The current classification of BoAstVs by the ICTV is: Riboviria $>$ Orthornavirae $>$ Pisuviricota $>$ Stelpaviricetes $>$ Stellavirales $>$ Astroviridae $>$ Mamastrovirus. Within the genus Mamastrovirus (MAstV), there are 19 species confirmed by the ICTV, and BoAstV has not been officially assigned to any of them, although it has been proposed that the BoAstV associated with encephalitis belong to MAstV-13 [87]. In addition, it has been proposed that BoAstVs belong to other species not yet recognized by the ICTV: MAstV-24, MAstV-28, MAstV-29, MAstV-30, and MAstV-33 [87], and recently, a novel species widely dispersed was described [88]. Up to now, two different serotypes have been described [89], but current phylogenetic evidence indicates that the diversity of BoAstVs circulating in cattle is probably greater [87]. 
The role of BoAstV in cases of diarrhea remains controversial, but there is some evidence of their association in some outbreaks of neonatal calf diarrhea [90-92]. BoAstV infects ileum dome epithelial cells on Peyer's patches, whereas infection in the small or large intestine has not been observed. It has been described that BoAstV infection is more severe in those cases of coinfection with other viruses such as torovirus and rotavirus [11]. On the other hand, calves infected with astrovirus alone did not develop the clinical disease [11]. Whether BoAstV is clinically relevant or plays a synergistic role in the development of diarrhea is still unclear [88]. It would not be striking that, as with other viruses, some strains are more virulent than others.

The role of astroviruses beyond enteritis has recently emerged as an object of study. Their role as the causal agent of encephalitis has been confirmed in cattle, as well as in other species, including humans. In recent years, and due to the discovery of these neurotropic BoAstVs, the number of studies on BoAstVs has greatly increased [93-99]. Furthermore, BoAstV was detected in calves with bovine respiratory disease (BRD) and was absent in asymptomatic calves in a case-control study [100]. There is increasing evidence of detection of AstV in respiratory samples from humans and other animals with acute respiratory disease [101-105]. The MAstV-28 species has been reported in respiratory samples of animals with respiratory disease $[100,105]$. In addition, this species was detected in the feces of a calf that died of pneumonia [88]. It was also documented the detection of AstV in a patient suffering respiratory disease and diarrhea, both in nasopharyngeal and stool samples [104]. Despite being highly probable, the role of BoAstV in respiratory disease still needs to be further studied to confirm or rule it out.

\section{Nebovirus}

The discovery of BoNeV dates back to 1978, jointly with BoNoV and BoAstV, in feces of diarrheic calves [54]. Neboviruses are non-enveloped of approximately $33 \mathrm{~nm}$ in diameter (Table 1), they have dark hollows on the surface of the particles (without a clear pattern), and some virions display a 10-spiked sphere morphology [106].

The BoNeV has a single-stranded positive-polarity RNA genome and 7453 nucleotides of length (Table 1). Similar to other members of Caliciviridae (but not Norovirus), BoNeV presents two ORFs flanked by two untranslated regions (UTR) $[107,108]$. The ORF-1 contains 6633 nucleotides and codifies for the non-structural and the major capsid proteins, while the ORF-2 consists of 678 nucleotides and encodes the minor capsid protein [107,108]. The $5^{\prime}$ UTR consists of 75 nucleotides and presents a conserved motif upstream the initiation codon, and the $3^{\prime}$ UTR consists of 67 nucleotides and contains a poly-A $[107,108]$.

Classified by ICTV as: Riboviria > Orthornavirae > Pisuviricota > Pisoniviricetes > Picornavirales > Caliciviridae > Nebovirus. The BoNeV are then members of a different genus to Norovirus within the Caliciviridae family. Within the genus, there is not a consensus classification, but three RNA-dependent RNA polymerase (RdRp) genotypes and three VP1 genotypes have been described [109]. Genotype 1 of VP1 can be further subdivided into four lineages that showed both temporal and geographical distribution $[109,110]$. In addition, recombinant events have been described both in the polymerase and in the capsid regions [111-114].

With regard to the disease, all the gnotobiotic calves challenged with BoNeV have shown clinical signs, mainly diarrhea [106,107]. The incubation period is 1 to 5 days, and preceding diarrhea, the calves usually develop anorexia. The feces change from browngreen to yellow with variable consistency $[106,107,115]$, and blood can be observed in the most severely affected calves [106]. Histopathologic lesions are limited to the small intestine following a general pattern with more severe pathological changes in the anterior small intestine than milder distally. Other observations include villus atrophy and D-xylose malabsorption [106,115]. Viral antigen was observed in the cytoplasm of enterocytes [115]. Interestingly, no major differences were observed between orally and i.v.-exposed calves in virus shedding or histopathologic lesions [107], intriguing about the transmission routes beyond the fecal-oral. On the other hand, no lesions were observed in tissues of other (non- 
small intestine) major organs. BoNeV shedding can be observed before the onset of symptoms, and detection of virus particles remains for several days post-infection [106-108].

\section{Pestivirus}

The bovine viral diarrhea virus (BVDV) is a pestivirus with highly diverse clinical signs and complicated pathogenicity $[116,117]$. The disease was described for the first time in 1946 [118,119], with evidence from 1941 [120] and was initially called X disease, although the cause remained undetermined until 1959 when a virus named Oregon C24V was isolated [121].

The pestiviruses possess a single-stranded positive-polarity RNA genome of approximately 12,300 nucleotides in length (Table 1). A single ORF encodes a single polyprotein that is cleaved into 11-12 structural and non-structural proteins, which is flanked at both ends by UTRs [122]. Pestiviruses possess an envelope (Table 1).

Pestiviruses were recently renamed using a host-independent scheme (King et al., 2018). The classification by ICTV is currently: Riboviria > Orthornavirae > Kitrinoviricota > Flasuviricetes $>$ Amarillovirales $>$ Flaviviridae $>$ Pestivirus. The species within the Pestivirus genus that affect cattle are Pestivirus A (formerly BVDV-1), Pestivirus B (formerly BVDV-2), Pestivirus $D$ (formerly border disease virus, BDV), and Pestivirus $H$ (formerly Hobi-like or BVDV-3) [123].

Initially, the disease was described as an acute enteric disease of cattle, characterized by outbreaks of diarrhea and erosive lesions of the digestive tract, and for this reason, it was named bovine viral diarrhea and the causal agent BVDV [124]. Based on the current understanding of the pathogenesis and the multiple clinical manifestations of BVDV, the names Pestivirus A, Pestivirus $B$, and Pestivirus $H$ seem to be more adequate. As stated, the clinical manifestations of the pestiviruses in cattle are multiple and diverse: subclinical, diarrhea, respiratory, reproductive, and mucosal disease [124]. Within each manifestation, there are several ranges of severity and clinical signs.

Regarding diarrhea, outbreaks in animals ranging from 6 months to 1 year of age may occur and are characterized by high morbidity and low or nonexistent fatality. There is evidence that in coinfections with other infectious agents, the pestiviruses can increase the severity of neonatal diarrhea. In addition, persistently infected calves may also develop diarrhea. On the other hand, in adult cattle, the disease is characterized by thrombocytopenia, which results in bloody diarrhea [124]. In the acute disease, the incubation period is approximately 5 to 7 days and is followed by a transient fever and leukopenia. Viremia occurs 4 to 5 days after infection and may persist for up to 15 days. Clinical findings include depression, anorexia, oculonasal discharge, occasionally oral lesions, diarrhea, and a decrease in milk production [124]. In some cases, a severe acute noncytopathic infection is observed. Clinical signs include the acute onset of diarrhea, pyrexia, decreased milk production, and oral ulcerations that were sometimes observed [124]. The most severe presentation of the disease is the mucosal disease, which is a sporadic form of infection, usually involving cattle ranging from 6 months to 2 years of age. In this clinical manifestation, the fatality rate is almost $100 \%$. Although the clinical signs are diverse, profuse, watery diarrhea generally develops 2 to 3 days after the onset of clinical signs. The feces are foul-smelling and may contain blood. In the chronic manifestation of the mucosal disease, among other symptoms, diarrhea (that can be continual or intermittent) may be observed [124].

\section{Kobuvirus}

The discovery of the bovine kobuvirus (BKV) was serendipitous; a cytopathogenic agent, named U-1 strain, was isolated from the culture medium of HeLa cells on Vero cells. In the same study, using RT-PCR, the virus was detected in fecal samples from cattle, and in addition, neutralizing antibodies were detected in serum samples also from cattle [125]. The name kobuvirus comes from the Japanese word "kobu", which means bump, as these viruses show a characteristic bumpy morphology under an electron microscope [126]. 
The BKV is non-enveloped and possesses a single-stranded, positive-sense RNA genome of approximately 8300 nucleotides of length (Table 1). The genome consists of a single ORF flanked by two UTRs $\left(5^{\prime}\right.$ and $\left.3^{\prime}\right)$. The polyprotein precursor consists of three distinct functional protein-encoded regions termed P1 (3 structural proteins), P2 (3 non-structural proteins), and P3 (4 non-structural proteins) [126].

The taxonomic classification by the ICTV is: Riboviria > Orthornavirae > Pisuviricota > Pisoniviricetes > Picornavirales > Picornaviridae > Kobuvirus > Aichivirus B. The Aichivirus B species consist of BKV (Aichivirus B1), ferret kobuvirus (Aichivirus B2), and ovine kobuvirus (Aichivirus B3) [126]. Currently, by phylogenetic analysis based on VP1, BKV can be divided into eight lineages [127], although there is not a consensus criterion for classification.

The role of BKV related to diarrhea is not clear at all. With the exception of isolation when discovered, it has not been possible to isolate the virus again, so the study has been limited. Histopathologic observation of small intestines of $4 \mathrm{BKV}$-positive calves revealed that two cases with diarrhea had necrotizing enteritis with villus atrophy and fusion, but two other calves without clinically evident diarrhea were positive for BKV [128]; it is not clear if the lesions observed were caused by BKV. Some studies have revealed higher detection rates in diarrheic than non-diarrheic calves [127,129], and some others studied/detected BKV in diarrheic calves [130-136], which may indicate a possible role in the disease. Recently, it was described a case of identification of Aichivirus B in a calf with enterocolitis and neurologic signs, but the possible role beyond enteritis was not confirmed [137]. The role of BKV in the disease remains unclear.

\section{Bocaparvovirus}

Bovine parvovirus (BPV) was discovered in the feces of five calves sampled in 1959 and was initially named HADEN (hemadsorbing enteric) virus [138]. The HADEN virus was proposed to belong to the enterovirus group [139], but a decade after the discovery, it was confirmed to be a parvovirus [140].

Unlike the ones mentioned above, the genome of BPV is a single-stranded DNA with a length of 5,491 nucleotides [141] (Table 1). This genome contains three ORFs that encode for four different proteins, flanked by non-identical palindromic terminal hairpins. ORF 1 encodes the non-structural NS1 protein, the ORF2 encodes the non-structural NP1 protein, while the ORF3 encodes two structural proteins VP1 and VP2 [142]. The non-structural protein NP1 is a unique feature of the bocaviruses [141,142]. Like the other members of the family, BPV is a non-enveloped virus (Table 1).

The classification of the BPV1 by the ICTV is: Monodnaviria > Shotokuvirae > Cossaviricota > Quintoviricetes > Piccovirales > Parvoviridae > Parvovirinae > Bocaparvovirus > Ungulate bocaparvovirus 1. Recently, a new species of bovine bocaparvovirus was characterized, Ungulate bocaparvovirus 6, but it was detected in respiratory samples [143]. In 2001, two other species of BPV were detected in serum samples [144], now classified as Ungulate erythroparvovirus 1 (genus: Erythroparvovirus) and Ungulate copiparvovirus 1 (genus: Copiparvovirus). Within BPV1, two serotypes have been recognized [145]. Unfortunately, the genetic diversity of these viruses has not been well explored.

Bocaparvoviruses cause gastroenteric, respiratory, and reproductive diseases [141]. BPV 1 (Ungulate bocaparvovirus 1) has been described as an enteric pathogen. Interestingly, nasally inoculated calves developed respiratory disease and diarrhea, while orally inoculated calves only developed diarrhea [146], which suggests that the route of entry may be a determining factor in terms of the disease developed. Regarding the enteric disease, after oral challenge with BPV, calves developed mild to moderate diarrhea 2 to 3 days after inoculation, with feces changing from formed pellets to fairly fluid, returning to normal feces after 5-7 days [147]. Other symptoms include mild fever, leucopenia, and lymphopenia on days 2 and 3, followed by leucocytosis and lymphocytosis on days 4 and 5 [147]. Regarding the gross pathology, the small intestine appears mildly congested and the contents watery, and the contents of the large intestine appear pasty and unformed. Small intestine (jejunum and ileum) villus atrophy and fusion due to crypt damage can be observed [147]. The virus 
can be isolated from rectal swabs as long as 12 days post-infection, increasing the risk of transmission [146]. Coinfection with other pathogens can exacerbate the disease caused by BPV $1[146,147]$.

\section{Enterovirus}

Bovine enteroviruses (BEV) were first isolated in the late 1950s [148] and were initially named enteric cytopathic bovine orphan virus. The name enterovirus comes from the Greek enteron, which means intestine. They have been isolated from cattle suffering respiratory, enteric, and reproductive diseases, but the respiratory and enteric diseases could not be reproduced experimentally using viral isolates from affected calves [149]. However, occasionally BEV could lead to fatal cases of enteric disease [150].

The genome of BEV is a single-stranded positive-sense RNA [151] (Table 1). Similar to other picornaviruses, BEVs are non-enveloped (Table 1). The genome is linked to a small polypeptide, $\mathrm{VPg}$. Excluding the poly(A), the genome is 7414 nucleotides long and contains a $5^{\prime}$ UTR (longer than that of most picornaviruses), a single ORF, and a $3^{\prime}$ UTR [152-154]. The single ORF encodes a polyprotein ranging from 2166 to 2176 amino acids [155] and is divided into three regions: P1, P2, and P3. The P1 region comprises the structural proteins VP1, VP2, VP3, and VP4, the P2 region comprises the non-structural proteins $2 \mathrm{~A}, 2 \mathrm{~B}$, and $2 \mathrm{C}$, whereas the $\mathrm{P} 3$ region comprises the non-structural proteins $3 \mathrm{~A}, 3 \mathrm{~B}(\mathrm{VPg}), 3 \mathrm{C}$ (protease) and 3D (polymerase) [152,153].

The complete classification of the enteroviruse by the ICTV is: Riboviria > Orthornavirae $>$ Pisuviricota > Pisoniviricetes > Picornavirales > Picornaviridae > Enterovirus. Within the genus Enterovirus, the BEV are members of the Enterovirus E and Enterovirus F species. Recently, a possible novel species was described [154]. Currently, there are two different serotypes that have been confirmed [156].

BEV infects mainly the colon and not the small intestine [157]. Through PCR and in situ hybridization (ISH), BEV was detected in the terminal ileum, cecum, and colon (near the cecocolonic junction). The hybridization signal was detected in the cytoplasm of enterocytes and cells within lamina propria (probably macrophages), in neurons of the submucosal and myenteric ganglia, vascular endothelium, submucosal lymphoid tissues, and ileocecal lymph nodes. In addition, the ISH signal was positive in the brain of a calf with encephalitis and in the coronary artery of another calf with mild multifocal coronary arteritis, suggesting that enteric infection could also be a route of entry for systemic infections [157]. Infected calves did not have signs of clinical disease, and very few gross lesions were observed at necropsy. However, all these results should be taken with caution since some control also became infected [157]. The role of BEV related to diarrhea is fairly to be clear but does not seem to be an important pathogen. However, they could probably be more important in extra-intestinal diseases that can be originated from enteric infections.

\section{Orthobunyavirus}

In 2011, outbreaks of a previously unidentified disease in dairy cattle characterized by a short period of clear clinical signs, including fever, decreased milk production, and diarrhea, were observed. The etiological agent was determined to be a novel orthobunyavirus named Schmallenberg virus (SBV) [158]. However, SBV-associated disease is of interest when immunologically naïve ruminants are infected during a critical period of gestation because SBV can cause abortion, stillbirth, or severe fetal malformations [159].

Orthobunyaviruses are enveloped and possess a single-stranded negative-sense RNA genome composed of three segments (Table 1).

The taxonomic classification of SBV is: Riboviria > Orthornavirae > Negarnaviricota > Polyploviricotina $>$ Ellioviricetes $>$ Bunyavirales $>$ Peribunyaviridae $>$ Orthobunyavirus $>$ Schmallenberg orthobunyavirus.

The SBV is transmitted by Culicoides midges. Regarding diarrhea, in the first animal challenge, the calf inoculated with SBV isolated with Culicoides variipennis larvae cells (KC cells) developed mucous diarrhea for several days [158]. In addition, a calf from a group 
of four that received culture-grown virus initially isolated in $\mathrm{KC}$ cells developed mild diarrhea for two days [160]. Interestingly, in these challenges, only calves inoculated with SBV isolated in KC cells developed diarrhea, while no calf inoculated with SBV but that were not isolated with Culicoides cells showed symptoms of diarrhea. In another study, diarrhea was observed in $83.2 \%$ of 350 clinically affected animals [161]. Despite all this, the role of SBV in cattle diarrhea appears to be secondary.

\section{General Characteristics}

\subsection{Prevention and Treatment of Viral Enteritis}

For most of the viruses reviewed, there are neither prevention nor control strategies nor specific treatment, which undoubtedly complicate the control of diarrhea, remaining as an endemic problem in many herds despite taking measures against some pathogens. However, reduction in the burden of the disease can be achieved through different strategies aimed at combating some of the most studied pathogens. These viral pathogens, for which there are prevention and/or treatment, are rotavirus, coronavirus, and pestivirus.

\subsubsection{Vaccines}

Despite adult cattle can be affected by diarrhea, strategies for preventing the disease are mainly focused on the first weeks of age when the disease (neonatal calf diarrhea) is generally more severe. In this sense, and considering the early susceptibility of calves to viruses' infection, the presence of passive antibodies (Abs, IgG1, and IgA) in the gut lumen plays an important role in protection against both viruses' infection and disease. In addition, high titers of passive circulating Abs possess a complementary role in protection against diarrhea due to the transfer of serum IgG1 into the intestine of neonatal calves [44]. To achieve this, vaccination has proven to be an effective method, either to prevent infection, or, in any case, to reduce the severity of the disease. The most widely used strategy is the vaccination of the dam weeks before calving, although oral administration to newborn calves has also been described.

There are several vaccines available worldwide. Most of them include both RVA and $\mathrm{BCoV}$ and can include other pathogens such as Escherichia coli. The coronavirus strain most widely used in the vaccines formulation is Mebus and has been demonstrated to be effective against coronavirus infection since, so far, a single serotype has been described [53]. In the case of rotavirus, vaccines usually include one or two strains of different $G$ and/or $P$ genotypes, but protection has been described to be genotype-dependent, with several reports of vaccine breakthrough events associated with heterotypic rotavirus [162-164]. On the other hand, an alternative strategy has been described, using recombinant VP6 to immunize cows, showing a reduction in both diarrhea and virus shedding (in terms of viral titer and excretion period) in comparison with colostrum-deprived calves [165].

As already mentioned, pestiviruses are not major viruses causing diarrhea, but we briefly review the prevention strategies available. The prevention of pestiviruses includes control programs, which can be classified as systematic (across a regional or national level) or non-systematic (at herd level) [123]. Furthermore, vaccination is a cost-effective measure for disease control. There are conventional modified live virus or inactivated virus vaccines, formulated as either pestivirus A and/or B preparations or multivalent vaccines, including other pathogens [123].

\subsubsection{Treatment}

Usually, no specific treatment against viruses is available. The treatment is based only on treating the symptoms, such as rehydration of the animals. Interestingly, IgY antibodies production against rotavirus and coronavirus in egg yolk has been developed as an effective treatment virus-specific. This strategy has been demonstrated to be effective in protecting both coronavirus- and rotavirus-induced diarrhea [166,167], and recently has been developed the first biological product available in the market for the prevention of virus-associated neonatal calf diarrhea [168]. 


\subsection{Geographic Distribution}

In general, these viruses are dispersed worldwide, some have been detected throughout the world, and others are not yet described, but probably they are present. In particular, some of these viruses have been detected in cattle worldwide, with reports from America, Europe, Asia, Africa, and Oceania, i.e., rotavirus, coronavirus, norovirus, pestivirus, and enterovirus. Others have been detected in America, Europe, Asia, and Africa, i.e., torovirus, astrovirus, nebovirus, kobuvirus. On the other hand, the bocaparvovirus have been detected in America, Europe, and Asia. Lastly, the SBV (orthobunyavirus) has been detected mainly in Europe and suggested to be also present in Africa and Asia.

\subsection{Interspecies Transmission}

The interspecies transmission has been documented for rotavirus [45], coronavirus [169], astrovirus [88,92], kobuvirus [131,170], pestivirus [171], and enterovirus [172,173]. Notably, the zoonotic potential has been discussed for rotavirus [45], coronavirus [174], nebovirus [175], and enterovirus [172,173].

\subsection{Viral Evolution}

The evolution of viruses with RNA genome is so fast that it can be studied in real time. In this sense, viruses with RNA genomes have been great examples to study evolutionary processes. Viruses evolve by using multiple genetic mechanisms, i.e., mutation, recombination, reassortment and/or interspecies transmission. The latter has been briefly described above.

In the case of mutations, it is the main process used by all the viruses, being the mutation rate very high, mainly in viruses with an RNA genome. The nucleotide substitution rates estimated for some of the viruses included in this review are: $1.39 \times 10^{-3}$ substitution per site per year (s/s/y) for BCoV [53], $1.58 \times 10^{-2} \mathrm{~s} / \mathrm{s} / \mathrm{y}$ for BKV [131], $4.27 \times 10^{-4} \mathrm{~s} / \mathrm{s} / \mathrm{y}$ for bovine astrovirus (associated with encephalitis) [99], $2.78 \times 10^{-3}$ $\mathrm{s} / \mathrm{s} / \mathrm{y}-3.81 \times 10^{-3}$ for BoNoV [176,177], $1.40 \times 10^{-2} \mathrm{~s} / \mathrm{s} / \mathrm{y}$ for BEV [178], $1.14 \times 10^{-2}$ $\mathrm{s} / \mathrm{s} / \mathrm{y}$ for SBV [179], $3 \times 10^{-3} \mathrm{~s} / \mathrm{s} / \mathrm{y}$ for BToV [180], and $5.90 \times 10^{-4}-9.3 \times 10^{-3}$ for bovine pestivirus $[122,181,182]$.

Genetic recombination is another process that has been described for some of these viruses, i.e., BCoV [183-185], BoNoV [60,66], BoAstV [86], BoNeV [111-113], BEV [155], BToV [180], BPV [186], and for pestivirus [187]. For RVA, recombination has been described, but until now, no RVA recombinants have been reported in cattle.

Regarding gene reassortment, it has been reported in RVA detected in cattle [45]. Interestingly, the emergence of the SBV has been suggested to be a Shamonda/Sathuperi virus reassortant [188].

\section{Conclusions}

Viral enteritis is an important cause of economic losses and has a negative impact on cattle welfare. The knowledge about the viruses that infect the intestinal tract is fundamental to direct strategies to control the disease and reduce the negative impact that it has on cattle production. Epidemiological and molecular surveillance is crucial to detect possible emergent viruses and/or viral variants with their potential pathogenicity for cattle.

Author Contributions: Writing—original draft preparation, M.C.; writing—review and editing, R.C. Both authors have read and agreed to the published version of the manuscript.

Funding: This research was funded by “Comisión Sectorial de Investigación Científica” (CSIC), grant number ini2017_158.

Institutional Review Board Statement: Not applicable.

Informed Consent Statement: Not applicable.

Data Availability Statement: Not applicable. 
Acknowledgments: M.C. and R.C. acknowledge support from Agencia Nacional de Investigación e Innovación (ANII) through Sistema Nacional de Investigadores.

Conflicts of Interest: The authors declare no conflict of interest. The funders had no role in the design of the study; in the collection, analyses, or interpretation of data; in the writing of the manuscript; or in the decision to publish the results.

\section{References}

1. Sansoucy, R. Livestock-A Driving Force for Food Security and Sustainable Development. 1997. Available online: http: //www.fao.org/3/v8180t/v8180t07.htm (accessed on 13 April 2021).

2. National Institute of Food Agiculture, USA. Available online: https://nifa.usda.gov/topic/animal-production (accessed on 13 April 2021).

3. Kaneene, J.B.; Hurd, H.S. The national animal health monitoring system in Michigan. III. Cost estimates of selected dairy cattle diseases. Prev. Vet. Med. 1990, 8, 127-140. [CrossRef]

4. Selman, I.E. The care of young calves, neonatal calf diarrhea, the calf pneumonias. In Diseases of Cattle in the Tropics. Current Topics in Veterinary Medicine and Animal Science; Ristic, M., McIntyre, I., Eds.; Springer: Dordrecht, The Netherlands, 1981 ; Volume 6. [CrossRef]

5. Blanchard, P.C. Diagnostics of dairy and beef cattle diarrhea. Vet. Clin. N. Am. Food Anim. Pract. 2012, 28, 443-464. [CrossRef] [PubMed]

6. Naylor, J.M. Neonatal Calf Diarrhea. Food Anim. Pract. 2009, 70-77. [CrossRef]

7. Heller, M.C.; Chigerwe, M. Diagnosis and Treatment of Infectious Enteritis in Neonatal and Juvenile Ruminants. Vet. Clin. N. Am. Food Anim. Pract. 2018, 34, 101-117. [CrossRef] [PubMed]

8. Murphy, F.A.; Gibbs, E.P.J.; Horzinek, M.C.; Studdert, M.J. Veterinary Virology: The Third Edition; Academic Press: Cambridge, MA, USA, 1999.

9. Jor, E.; Myrmel, M.; Jonassen, C.M. SYBR Green based real-time RT-PCR assay for detection and genotype prediction of bovine noroviruses and assessment of clinical significance in Norway. J. Virol. Methods 2010, 169, 1-7. [CrossRef] [PubMed]

10. Archambault, D.; Morin, G.; Elazhary, Y.; Roy, R.S. Study of virus excretion in feces of diarrheic and asymptomatic calves infected with rotavirus. Zentralbl. Veterinarmed. B 1990, 37, 73-76. [CrossRef] [PubMed]

11. Woode, G.N.; Pohlenz, J.F.; Gourley, N.E.; Fagerland, J.A. Astrovirus and Breda virus infections of dome cell epithelium of bovine ileum. J. Clin. Microbiol. 1984, 19, 623-630. [CrossRef] [PubMed]

12. Saif, L.J. Bovine respiratory coronavirus. Vet. Clin. N. Am. Food Anim. Pract. 2010, 26, 349-364. [CrossRef]

13. Cho, Y.I.; Yoon, K.J. An overview of calf diarrhea-infectious etiology, diagnosis, and intervention. J. Vet. Sci. 2014, 15, 1-17. [CrossRef]

14. Maclachlan, N.J.; Dubovi, E.J.; Barthold, S.W.; Swayne, D.E.; Winton, J.R. Fenner's Veterinary Virology: Fifth Edition; Academic Press: Cambridge, MA, USA, 2016.

15. Waltner-Toews, D.; Martin, S.W.; Meek, A.H. The effect of early calfhood health status on survivorship and age at first calving. Can. J. Vet. Res. 1986, 50, 314-317.

16. Donovan, G.A.; Dohoo, I.R.; Montgomery, D.M.; Bennett, F.L. Calf and disease factors affecting growth in female Holstein calves in Florida, USA. Prev. Vet. Med. 1998, 33, 1-10. [CrossRef]

17. Windeyer, M.C.; Leslie, K.E.; Godden, S.M.; Hodgins, D.C.; Lissemore, K.D.; LeBlanc, S.J. Factors associated with morbidity, mortality, and growth of dairy heifer calves up to 3 months of age. Prev. Vet. Med. 2014, 113, 231-240. [CrossRef]

18. United States Department of Agriculture, USA. Part II: Reference of 1997 Beef Cow-Calf Health \& Health Management Practices. 1997. Available online: https://www.aphis.usda.gov/animal_health/nahms/beefcowcalf/downloads/beef97/Beef97_dr_PartII. pdf (accessed on 13 April 2021).

19. Smith, G.W. Treatment of calf diarrhea: Oral fluid therapy. Vet. Clin. N. Am. Food Anim. Pract. 2009, 25, 55-72. [CrossRef]

20. Smith, D.R. Field disease diagnostic investigation of neonatal calf diarrhea. Vet. Clin. N. Am. Food Anim. Pract. 2012, $28,465481$. [CrossRef] [PubMed]

21. Hur, T.Y.; Jung, Y.H.; Choe, C.Y.; Cho, Y.I.; Kang, S.J.; Lee, H.J.; Ki, K.S.; Baek, K.S.; Suh, G.H. The dairy calf mortality: The causes of calf death during ten years at a large dairy farm in Korea. Korean J. Vet. Res. 2013, 53, 103-108. [CrossRef]

22. Hötzel, M.J.; Longo, C.; Balcão, L.F.; Cardoso, C.S.; Costa, J.H. A survey of management practices that influence performance and welfare of dairy calves reared in southern Brazil. PLoS ONE 2014, 15, e114995. [CrossRef]

23. Mõtus, K.; Viltrop, A.; Emanuelson, U. Reasons and risk factors for beef calf and youngstock on-farm mortality in extensive cow-calf herds. Animal 2018, 12, 1958-1966. [CrossRef]

24. Urie, N.J.; Lombard, J.E.; Shivley, C.B.; Kopral, C.A.; Adams, A.E.; Earleywine, T.J.; Olson, J.D.; Garry, F.B. Preweaned heifer management on US dairy operations: Part, V. Factors associated with morbidity and mortality in preweaned dairy heifer calves. J. Dairy Sci. 2018, 101, 9229-9244. [CrossRef]

25. Roche, S.M.; Von Massow, M.; Renaud, D.; Shock, D.A.; Jones-Bitton, A.; Kelton, D.F. Cost-benefit of implementing a participatory extension model for improving on-farm adoption of Johne's disease control recommendations. J. Dairy Sci. 2020, 103, 451-472. [CrossRef] 
26. Abuelo, A.; Cullens, F.; Brester, J.L. Effect of preweaning disease on the reproductive performance and first-lactation milk production of heifers in a large dairy herd. J. Dairy Sci. 2021, 104, 7008-7017. [CrossRef] [PubMed]

27. Saif, L.J. A review of evidence implicating bovine coronavirus in the etiology of winter dysentery in cows: An enigma resolved? Cornell Vet. 1990, 80, 303-311. [PubMed]

28. Clark, M.A. Bovine coronavirus. Br. Vet. J. 1993, 149, 51-70. [CrossRef]

29. Aita, T.; Kuwabara, M.; Murayama, K.; Sasagawa, Y.; Yabe, S.; Higuchi, R.; Tamura, T.; Miyazaki, A.; Tsunemitsu, H. Characterization of epidemic diarrhea outbreaks associated with bovine torovirus in adult cows. Arch. Virol. 2012, 157, 423-431. [CrossRef] [PubMed]

30. Constable, P.D.; Hinchcliff, K.W.; Done, S.H.; Grünberg, W. Veterinary Medicine: A Textbook of the Diseases of Cattle, Horses, Sheep, Pigs, and Goats, 11th ed.; Elsevier: Amsterdam, The Netherlands, 2016.

31. Van Kruiningen, H.J.; Castellano, V.P.; Koopmans, M.; Harris, L.L. A serologic investigation for coronavirus and Breda virus antibody in winter dysentery of dairy cattle in the northeastern United States. J. Vet. Diagn. Investig. 1992, 4, 450-452. [CrossRef] [PubMed]

32. World Organization for Animal Health (OIE). Declaration of Global Eradication of Rinderpest and Implementation of Follow-Up Measures to Maintain World Freedom from Rinderpest. 2011. Available online: http:/ /www.oie.int/fileadmin/Home/eng/ Media_Center/docs/pdf/RESO_18_EN.pdf (accessed on 16 April 2021).

33. Normile, D. Driven to Extinction. Science 2008, 319, 1606-1609. [CrossRef]

34. Butler, D. Sequence and destroy: The quest to eliminate the last stocks of deadly rinderpest virus. Nature 2019, 572, 18. [CrossRef] [PubMed]

35. King, S.; Rajko-Nenow, P.; Ropiak, H.M.; Ribeca, P.; Batten, C.; Baron, M.D. Full genome sequencing of archived wild type and vaccine rinderpest virus isolates prior to their destruction. Sci. Rep. 2020, 10, 6563. [CrossRef]

36. Roeder, P.L.; Rich, K. The Global Effort to Eradicate Rinderpest. 2009. Available online: http://ebrary.ifpri.org/utils/getfile/ collection/p15738coll2/id/29876/filename/29877.pdf (accessed on 16 April 2021).

37. Mebus, C.A.; Underdahl, N.R.; Rhodes, M.B.; Twiehaus, M.J. Calf diarrhea (scours): Reproduced with a virus from a field outbreak. Bull. Neb. Agric Exp. Station 1969, 233, 1-16.

38. Garaicoechea, L.; Bok, K.; Jones, L.R.; Combessies, G.; Odeón, A.; Fernandez, F.; Parreño, V. Molecular characterization of bovine rotavirus circulating in beef and dairy herds in Argentina during a 10-year period (1994-2003). Vet. Microbiol. 2006, $26,1-11$. [CrossRef] [PubMed]

39. Dhama, K.; Chauhan, R.S.; Mahendran, M.; Malik, S.V. Rotavirus diarrhea in bovines and other domestic animals. Vet. Res. Commun. 2009, 33, 1-23. [CrossRef]

40. Estes, M.; Greenberg, H. Rotaviruses. In Fields Virology, 6th ed.; Knipe, D.M., Howley, P.M., Cohen, J.I., Griffin, D.E., Lamb, R.A., Martin, M.A., Racaniello, V.R., Roizman, B., Eds.; Wolters Kluwer Business/Lippincott Williams and Wilkins: Philadelphia, PA, USA, 2013.

41. Matthijnssens, J.; Ciarlet, M.; McDonald, S.M.; Attoui, H.; Bányai, K.; Brister, J.R.; Buesa, J.; Esona, M.D.; Estes, M.K.; Gentsch, J.R.; et al. Uniformity of rotavirus strain nomenclature proposed by the Rotavirus Classification Working Group (RCWG). Arch. Virol. 2011, 156, 1397-1413. [CrossRef]

42. Papp, H.; László, B.; Jakab, F.; Ganesh, B.; De Grazia, S.; Matthijnssens, J.; Ciarlet, M.; Martella, V.; Bányai, K. Review of group A rotavirus strains reported in swine and cattle. Vet. Microbiol. 2013, 30, 190-199. [CrossRef]

43. Matthijnssens, J.; Ciarlet, M.; Heiman, E.; Arijs, I.; Delbeke, T.; McDonald, S.M.; Palombo, E.A.; Iturriza-Gómara, M.; Maes, P.; Patton, J.T.; et al. Full genome-based classification of rotaviruses reveals a common origin between human Wa-Like and porcine rotavirus strains and human DS-1-like and bovine rotavirus strains. J. Virol. 2008, 82, 3204-3219. [CrossRef]

44. Parreño, V.; Béjar, C.; Vagnozzi, A.; Barrandeguy, M.; Costantini, V.; Craig, M.I.; Yuan, L.; Hodgins, D.; Saif, L.; Fernández, F. Modulation by colostrum-acquired maternal antibodies of systemic and mucosal antibody responses to rotavirus in calves experimentally challenged with bovine rotavirus. Vet. Immunol. Immunopathol. 2004, 100, 7-24. [CrossRef]

45. Castells, M.; Caffarena, R.D.; Casaux, M.L.; Schild, C.; Miño, S.; Castells, F.; Castells, D.; Victoria, M.; Riet-Correa, F.; Giannitti, F.; et al. Phylogenetic Analyses of Rotavirus A from Cattle in Uruguay Reveal the Circulation of Common and Uncommon Genotypes and Suggest Interspecies Transmission. Pathogens 2020, 14, 570. [CrossRef]

46. Badaracco, A.; Garaicoechea, L.; Matthijnssens, J.; Louge Uriarte, E.; Odeón, A.; Bilbao, G.; Fernandez, F.; Parra, G.I.; Parreño, V. Phylogenetic analyses of typical bovine rotavirus genotypes G6, G10, P[5] and P[11] circulating in Argentinean beef and dairy herds. Infect. Genet. Evol. 2013, 18, 18-30. [CrossRef] [PubMed]

47. Stair, E.L.; Rhodes, M.B.; White, R.G.; Mebus, C.A. Neonatal calf diarrhea: Purification and electron microscopy of a coronaviruslike agent. Am. J. Vet. Res. 1972, 33, 1147-1156. [PubMed]

48. Mebus, C.A.; Stair, E.L.; Rhodes, M.B.; Twiehaus, M.J. Pathology of neonatal calf diarrea induced by a coronavirus-like agent. Vet. Pathol. 1973, 10, 45-64. [CrossRef] [PubMed]

49. Masters, P.S. The molecular biology of coronaviruses. Adv. Virus Res. 2006, 66, 193-292. [CrossRef]

50. Casanova, L.; Rutala, W.A.; Weber, D.J.; Sobsey, M.D. Survival of surrogate coronaviruses in water. Water Res. 2009, 43, 1893-1898. [CrossRef]

51. Mullis, L.; Saif, L.J.; Zhang, Y.; Zhang, X.; Azevedo, M.S. Stability of bovine coronavirus on lettuce surfaces under household refrigeration conditions. Food Microbiol. 2012, 30, 180-186. [CrossRef] 
52. Bok, M.; Alassia, M.; Frank, F.; Vega, C.G.; Wigdorovitz, A.; Parreño, V. Passive immunity to control Bovine coronavirus diarrhea in a dairy herd in Argentina. Rev. Argent. Microbiol. 2018, 50, 23-30. [CrossRef]

53. Castells, M.; Giannitti, F.; Caffarena, R.D.; Casaux, M.L.; Schild, C.; Castells, D.; Riet-Correa, F.; Victoria, M.; Parreño, V.; Colina, R. Bovine coronavirus in Uruguay: Genetic diversity, risk factors and transboundary introductions from neighboring countries. Arch. Virol. 2019, 164, 2715-2724. [CrossRef] [PubMed]

54. Woode, G.N.; Bridger, J.C. Isolation of small viruses resembling astroviruses and caliciviruses from acute enteritis of calves. J. Med. Microbiol. 1978, 11, 441-452. [CrossRef] [PubMed]

55. Van Der Poel, W.H.; Vinjé, J.; van Der Heide, R.; Herrera, M.I.; Vivo, A.; Koopmans, M.P. Norwalk-like calicivirus genes in farm animals. Emerg. Infect. Dis. 2000, 6, 36-41. [CrossRef] [PubMed]

56. Deng, Y.; Batten, C.A.; Liu, B.L.; Lambden, P.R.; Elschner, M.; Günther, H.; Otto, P.; Schnürch, P.; Eichhorn, W.; Herbst, W.; et al. Studies of epidemiology and seroprevalence of bovine noroviruses in Germany. J. Clin. Microbiol. 2003, 41, 2300-2305. [CrossRef] [PubMed]

57. Van der Poel, W.H.; van der Heide, R.; Verschoor, F.; Gelderblom, H.; Vinjé, J.; Koopmans, M.P. Epidemiology of Norwalk-like virus infections in cattle in The Netherlands. Vet. Microbiol. 2003, 92, 297-309. [CrossRef]

58. Milnes, A.S.; Binns, S.H.; Oliver, S.L.; Bridger, J.C. Retrospective study of noroviruses in samples of diarrhoea from cattle, using the Veterinary Laboratories Agency's Farmfile database. Vet. Rec. 2007, 160, 326-330. [CrossRef]

59. Ferragut, F.; Vega, C.G.; Mauroy, A.; Conceição-Neto, N.; Zeller, M.; Heylen, E.; Uriarte, E.L.; Bilbao, G.; Bok, M.; Matthijnssens, J.; et al. Molecular detection of bovine Noroviruses in Argentinean dairy calves: Circulation of a tentative new genotype. Infect. Genet. Evol. 2016, 40, 144-150. [CrossRef]

60. Cho, Y.I.; Han, J.I.; Wang, C.; Cooper, V.; Schwartz, K.; Engelken, T.; Yoon, K.J. Case-control study of microbiological etiology associated with calf diarrhea. Vet. Microbiol. 2013, 166, 375-385. [CrossRef]

61. Castells, M.; Caffarena, R.D.; Casaux, M.L.; Schild, C.; Castells, F.; Castells, D.; Victoria, M.; Riet-Correa, F.; Giannitti, F.; Parreño, V.; et al. Detection, risk factors and molecular diversity of GIII norovirus in Uruguay. Infect. Genet. Evol. $2020,3,104613$. [CrossRef]

62. Prasad, B.V.; Hardy, M.E.; Dokland, T.; Bella, J.; Rossmann, M.G.; Estes, M.K. X-ray crystallographic structure of the Norwalk virus capsid. Science 1999, 286, 287-290. [CrossRef] [PubMed]

63. Scipioni, A.; Mauroy, A.; Vinjé, J.; Thiry, E. Animal noroviruses. Vet. J. 2008, 178, 32-45. [CrossRef] [PubMed]

64. Daughenbaugh, K.F.; Fraser, C.S.; Hershey, J.W.; Hardy, M.E. The genome-linked protein VPg of the Norwalk virus binds eIF3, suggesting its role in translation initiation complex recruitment. EMBO J. 2003, 22, 2852-2859. [CrossRef] [PubMed]

65. Goodfellow, I.; Chaudhry, Y.; Gioldasi, I.; Gerondopoulos, A.; Natoni, A.; Labrie, L.; Laliberté, J.F.; Roberts, L. Calicivirus translation initiation requires an interaction between VPg and eIF 4 E. EMBO Rep. 2005, 6, 968-972. [CrossRef]

66. Bull, R.A.; Tanaka, M.M.; White, P.A. Norovirus recombination. J. Gen. Virol. 2007, 88 Pt 12, 3347-3359. [CrossRef]

67. Wang, Y.; Yue, H.; Tang, C. Prevalence and complete genome of bovine norovirus with novel VP1 genotype in calves in China. Sci. Rep. 2019, 9, 12023. [CrossRef]

68. Otto, P.H.; Clarke, I.N.; Lambden, P.R.; Salim, O.; Reetz, J.; Liebler-Tenorio, E.M. Infection of calves with bovine norovirus GIII.1 strain Jena virus: An experimental model to study the pathogenesis of norovirus infection. J. Virol. 2011, 85, 12013-12021. [CrossRef]

69. Jung, K.; Scheuer, K.A.; Zhang, Z.; Wang, Q.; Saif, L.J. Pathogenesis of GIII.2 bovine norovirus, CV186-OH/00/US strain in gnotobiotic calves. Vet. Microbiol. 2014, 168, 202-207. [CrossRef]

70. Sawyer, L.A.; Murphy, J.J.; Kaplan, J.E.; Pinsky, P.F.; Chacon, D.; Walmsley, S.; Schonberger, L.B.; Phillips, A.; Forward, K.; Goldman, C.; et al. 25- to 30-nm virus particle associated with a hospital outbreak of acute gastroenteritis with evidence for airborne transmission. Am. J. Epidemiol. 1988, 127, 1261-1271. [CrossRef]

71. Duizer, E.; Bijkerk, P.; Rockx, B.; De Groot, A.; Twisk, F.; Koopmans, M. Inactivation of caliciviruses. Appl. Environ. Microbiol. 2004, 70, 4538-4543. [CrossRef]

72. Rzezutka, A.; Cook, N. Survival of human enteric viruses in the environment and food. FEMS Microbiol. Rev. 2004, 28, 441-453. [CrossRef]

73. Nims, R.; Plavsic, M. Inactivation of caliciviruses. Pharmaceuticals 2013, 6, 358-392. [CrossRef]

74. Woode, G.N.; Reed, D.E.; Runnels, P.L.; Herrig, M.A.; Hill, H.T. Studies with an unclassified virus isolated from diarrheic calves. Vet. Microbiol. 1982, 7, 221-240. [CrossRef]

75. Horzinek, M.C.; Flewett, T.H.; Saif, L.J.; Spaan, W.J.; Weiss, M.; Woode, G.N. A new family of vertebrate viruses: Toroviridae. Intervirology 1987, 27, 17-24. [CrossRef]

76. Draker, R.; Roper, R.L.; Petric, M.; Tellier, R. The complete sequence of the bovine torovirus genome. Virus Res. 2006, 115, 56-68. [CrossRef] [PubMed]

77. Duckmanton, L.M.; Tellier, R.; Liu, P.; Petric, M. Bovine torovirus: Sequencing of the structural genes and expression of the nucleocapsid protein of Breda virus. Virus Res. 1998, 58, 83-96. [CrossRef]

78. Cavanagh, D.; Horzinek, M.C. Genus Torovirus assigned to the Coronaviridae. Arch. Virol. 1993, 128, 395-396. [CrossRef] [PubMed]

79. González, J.M.; Gomez-Puertas, P.; Cavanagh, D.; Gorbalenya, A.E.; Enjuanes, L. A comparative sequence analysis to revise the current taxonomy of the family Coronaviridae. Arch. Virol. 2003, 148, 2207-2235. [CrossRef] 
80. Hoet, A.E.; Saif, L.J. Bovine torovirus (Breda virus) revisited. Anim. Health Res. Rev. 2004, 5, 157-171. [CrossRef]

81. Hoet, A.E.; Cho, K.O.; Chang, K.O.; Loerch, S.C.; Wittum, T.E.; Saif, L.J. Enteric and nasal shedding of bovine torovirus (Breda virus) in feedlot cattle. Am. J. Vet. Res. 2002, 63, 342-348. [CrossRef]

82. Koopmans, M.; Horzinek, M.C. Toroviruses of animals and humans: A review. Adv. Virus Res. 1994, 43, 233-273. [CrossRef] [PubMed]

83. Hall, G.A. Comparative pathology of infection by novel diarrhoea viruses. Ciba Found. Symp. 1987, 128, 192-217. [CrossRef] [PubMed]

84. Pohlenz, J.F.; Cheville, N.F.; Woode, G.N.; Mokresh, A.H. Cellular lesions in intestinal mucosa of gnotobiotic calves experimentally infected with a new unclassified bovine virus (Breda virus). Vet. Pathol. 1984, 21, 407-417. [CrossRef] [PubMed]

85. Holmes, K.V. Enteric infections with coronaviruses and toroviruses. Novartis Found. Symp. 2001, 238, 258-275. [CrossRef]

86. Tse, H.; Chan, W.M.; Tsoi, H.W.; Fan, R.Y.; Lau, C.C.; Lau, S.K.; Woo, P.C.; Yuen, K.Y. Rediscovery and genomic characterization of bovine astroviruses. J. Gen. Virol. 2011, 92 Pt 8, 1888-1898. [CrossRef]

87. Donato, C.; Vijaykrishna, D. The broad host range and genetic diversity of mammalian and avian astroviruses. Viruses 2017, 9 , 102. [CrossRef] [PubMed]

88. Castells, M.; Bertoni, E.; Caffarena, R.D.; Casaux, M.L.; Schild, C.; Victoria, M.; Riet-Correa, F.; Giannitti, F.; Parreño, V.; Colina, R. Bovine Astrovirus Surveillance in Uruguay Reveals High Detection Rate of a Novel Mamastrovirus Species. Viruses $2019,12,32$. [CrossRef]

89. Woode, G.N.; Gourley, N.E.; Pohlenz, J.F.; Liebler, E.M.; Mathews, S.L.; Hutchinson, M.P. Serotypes of bovine astrovirus. J. Clin. Microbiol. 1985, 22, 668-670. [CrossRef]

90. Oem, J.K.; An, D.J. Phylogenetic analysis of bovine astrovirus in Korean cattle. Virus Genes 2014, 48, 372-375. [CrossRef]

91. Alfred, N.; Liu, H.; Li, M.L.; Hong, S.F.; Tang, H.B.; Wei, Z.Z.; Chen, Y.; Li, F.K.; Zhong, Y.Z.; Huang, W.J. Molecular epidemiology and phylogenetic analysis of diverse bovine astroviruses associated with diarrhea in cattle and water buffalo calves in China. J. Vet. Med. Sci. 2015, 77, 643-651. [CrossRef] [PubMed]

92. Nagai, M.; Omatsu, T.; Aoki, H.; Otomaru, K.; Uto, T.; Koizumi, M.; Minami-Fukuda, F.; Takai, H.; Murakami, T.; Masuda, T.; et al. Full genome analysis of bovine astrovirus from fecal samples of cattle in Japan: Identification of possible interspecies transmission of bovine astrovirus. Arch. Virol. 2015, 160, 2491-2501. [CrossRef] [PubMed]

93. Li, L.; Diab, S.; McGraw, S.; Barr, B.; Traslavina, R.; Higgins, R.; Talbot, T.; Blanchard, P.; Rimoldi, G.; Fahsbender, E.; et al. Divergent astrovirus associated with neurologic disease in cattle. Emerg. Infect. Dis. 2013, 19, 1385-1392. [CrossRef]

94. Bouzalas, I.G.; Wüthrich, D.; Selimovic-Hamza, S.; Drögemüller, C.; Bruggmann, R.; Seuberlich, T. Full-genome based molecular characterization of encephalitis-associated bovine astroviruses. Infect. Genet. Evol. 2016, 44, 162-168. [CrossRef]

95. Bouzalas, I.G.; Wüthrich, D.; Walland, J.; Drögemüller, C.; Zurbriggen, A.; Vandevelde, M.; Oevermann, A.; Bruggmann, R.; Seuberlich, T. Neurotropic astrovirus in cattle with nonsuppurative encephalitis in Europe. J. Clin. Microbiol. 2014, 52, 3318-3324. [CrossRef]

96. Schlottau, K.; Schulze, C.; Bilk, S.; Hanke, D.; Höper, D.; Beer, M.; Hoffmann, B. Detection of a Novel Bovine Astrovirus in a Cow with Encephalitis. Transbound. Emerg. Dis. 2016, 63, 253-259. [CrossRef] [PubMed]

97. Selimovic-Hamza, S.; Boujon, C.L.; Hilbe, M.; Oevermann, A.; Seuberlich, T. Frequency and Pathological Phenotype of Bovine Astrovirus CH13/NeuroS1 Infection in Neurologically-Diseased Cattle: Towards Assessment of Causality. Viruses 2017, 9, 12. [CrossRef]

98. Hirashima, Y.; Okada, D.; Shibata, S.; Yoshida, S.; Fujisono, S.; Omatsu, T.; Mizutani, T.; Nagai, M. Whole genome analysis of a novel neurotropic bovine astrovirus detected in a Japanese black steer with non-suppurative encephalomyelitis in Japan. Arch. Virol. 2018, 163, 2805-2810. [CrossRef]

99. Giannitti, F.; Caffarena, R.D.; Pesavento, P.; Uzal, F.A.; Maya, L.; Fraga, M.; Colina, R.; Castells, M. The first case of bovine astrovirus-associated encephalitis in the southern hemisphere (Uruguay) uncovers evidence of viral introduction to the Americas from Europe. Front. Microbiol. 2019, 10, 1240. [CrossRef]

100. Ng, T.F.; Kondov, N.O.; Deng, X.; Van Eenennaam, A.; Neibergs, H.L.; Delwart, E. A metagenomics and case-control study to identify viruses associated with bovine respiratory disease. J. Virol. 2015, 89, 5340-5349. [CrossRef]

101. Cordey, S.; Brito, F.; Vu, D.L.; Turin, L.; Kilowoko, M.; Kyungu, E.; Genton, B.; Zdobnov, E.M.; D'Acremont, V.; Kaiser, L. Astrovirus VA1 identified by next-generation sequencing in a nasopharyngeal specimen of a febrile Tanzanian child with acute respiratory disease of unknown etiology. Emerg. Microbes Infect. 2016, 6, e67.

102. Padmanabhan, A.; Hause, B.M. Detection and characterization of a novel genotype of porcine astrovirus 4 from nasal swabs from pigs with acute respiratory disease. Arch. Virol. 2016, 161, 2575-2579. [CrossRef]

103. Li, Y.; Khalafalla, A.I.; Paden, C.R.; Yusof, M.F.; Eltahir, Y.M.; Al Hammadi, Z.M.; Tao, Y.; Queen, K.; Hosani, F.A.; Gerber, S.I.; et al. Identification of diverse viruses in upper respiratory samples in dromedary camels from United Arab Emirates. PLoS ONE 2017, 13, e0184718. [CrossRef]

104. Cordey, S.; Zanella, M.C.; Wagner, N.; Turin, L.; Kaiser, L. Novel human astroviruses in pediatric respiratory samples: A one-year survey in a Swiss tertiary care hospital. J. Med. Virol. 2018, 90, 1775-1778. [CrossRef] [PubMed]

105. Wang, L.; Shen, H.; Zheng, Y.; Schumacher, L.; Li, G. Astrovirus in White-Tailed Deer, United States, 2018. Emerg. Infect. Dis. 2020, 26, 374-376. [CrossRef] [PubMed] 
106. Bridger, J.C.; Hall, G.A.; Brown, J.F. Characterization of a calici-like virus (Newbury agent) found in association with astrovirus in bovine diarrhea. Infect. Immun. 1984, 43, 133-138. [CrossRef] [PubMed]

107. Smiley, J.R.; Chang, K.O.; Hayes, J.; Vinjé, J.; Saif, L.J. Characterization of an enteropathogenic bovine calicivirus representing a potentially new calicivirus genus. J. Virol. 2002, 76, 10089-10098. [CrossRef]

108. Oliver, S.L.; Asobayire, E.; Dastjerdi, A.M.; Bridger, J.C. Genomic characterization of the unclassified bovine enteric virus Newbury agent-1 (Newbury1) endorses a new genus in the family Caliciviridae. Virology 2006, 20, 240-250. [CrossRef]

109. Guo, Z.; He, Q.; Zhang, B.; Yue, H.; Tang, C. First detection of neboviruses in yak (Bos grunniens) and identification of a novel neboviruses based on complete genome. Vet. Microbiol. 2019, 236, 108388. [CrossRef]

110. D'Mello, F.; Jervis, S.M.; Edwards, P.M.; Oliver, S.L.; Bridger, J.C. Heterogeneity in the capsid protein of bovine enteric caliciviruses belonging to a new genus. Virology 2009, 25, 109-116. [CrossRef]

111. Di Martino, B.; Di Profio, F.; Martella, V.; Ceci, C.; Marsilio, F. Evidence for recombination in neboviruses. Vet. Microbiol. 2011, 15, 367-372. [CrossRef] [PubMed]

112. Guo, Z.; He, Q.; Yue, H.; Zhang, B.; Tang, C. Genomic characterization of a RdRp-recombinat nebovirus strain with a novel VP1 genotype. Virus Res. 2018, 2, 6-13. [CrossRef] [PubMed]

113. Guo, Z.; He, Q.; Zhang, B.; Yue, H.; Tang, C. Detection and molecular characteristics of neboviruses in dairy cows in China. J. Gen. Virol. 2019, 100, 35-45. [CrossRef]

114. Karayel-Hacioglu, I.; Alkan, F. Molecular characterization of bovine noroviruses and neboviruses in Turkey: Detection of recombinant strains. Arch. Virol. 2019, 164, 1411-1417. [CrossRef] [PubMed]

115. Hall, G.A.; Bridger, J.C.; Brooker, B.E.; Parsons, K.R.; Ormerod, E. Lesions of gnotobiotic calves experimentally infected with a calicivirus-like (Newbury) agent. Vet. Pathol. 1984, 21, 208-215. [CrossRef] [PubMed]

116. Goens, S.D. The evolution of bovine viral diarrhea: A review. Can. Vet. J. 2002, 43, 946-954.

117. Stalder, H.; Bachofen, C.; Schweizer, M.; Zanoni, R.; Sauerländer, D.; Peterhans, E. Traces of history conserved over 600 years in the geographic distribution of genetic variants of an RNA virus: Bovine viral diarrhea virus in Switzerland. PLoS ONE 2018, 5, e0207604. [CrossRef]

118. Childs, T. X Disease of Cattle-Saskatchewan. Can. J. Comp. Med. Vet. Sci. 1946, 10, 316-319.

119. Olafson, P.; MacCallum, A.D.; Fox, F.H. An apparently new transmissible disease of cattle. Cornell Vet. 1946, 36, $205-213$.

120. Olafson, P.; Rickard, C.G. Further observations on the virus diarrhea (new transmissible disease) of cattle. Cornell Vet. 1947, 37, 104-106.

121. Gillespie, J.H.; Baker, J.A.; McEntee, K. A cytopathogenic strain of virus diarrhea virus. Cornell Vet. 1960, 50, 73-79.

122. Maya, L.; Macías-Rioseco, M.; Silveira, C.; Giannitti, F.; Castells, M.; Salvo, M.; Rivero, R.; Cristina, J.; Gianneechini, E.; Puentes, R.; et al. An extensive field study reveals the circulation of new genetic variants of subtype 1a of bovine viral diarrhea virus in Uruguay. Arch. Virol. 2020, 165, 145-156. [CrossRef]

123. Riitho, V.; Strong, R.; Larska, M.; Graham, S.P.; Steinbach, F. Bovine Pestivirus Heterogeneity and Its Potential Impact on Vaccination and Diagnosis. Viruses 2020, 6, 1134. [CrossRef]

124. Baker, J.C. The clinical manifestations of bovine viral diarrhea infection. Vet. Clin. N. Am. Food Anim Pract. 1995, 11, 425-445. [CrossRef]

125. Yamashita, T.; Ito, M.; Kabashima, Y.; Tsuzuki, H.; Fujiura, A.; Sakae, K. Isolation and characterization of a new species of kobuvirus associated with cattle. J. Gen. Virol. 2003, 84 Pt 11, 3069-3077. [CrossRef]

126. Hao, L.; Chen, C.; Bailey, K.; Wang, L. Bovine kobuvirus-A comprehensive review. Transbound. Emerg. Dis. 2020, 68, 1886-1894. [CrossRef] [PubMed]

127. Li, H.; Tang, C.; Yue, H. Molecular detection and genomic characteristics of bovine kobuvirus from dairy calves in China. Infect. Genet. Evol. 2019, 74, 103939. [CrossRef] [PubMed]

128. Wang, L.; Fredrickson, R.; Duncan, M.; Samuelson, J.; Hsiao, S.H. Bovine Kobuvirus in Calves with Diarrhea, United States. Emerg. Infect. Dis. 2020, 26, 176-178. [CrossRef] [PubMed]

129. Candido, M.; Batinga, M.C.; Alencar, A.L.; de Almeida-Queiroz, S.R.; da Glória Buzinaro, M.; Livonesi, M.C.; Fernandes, A.M.; de Sousa, R.L. Molecular characterization and genetic diversity of bovine Kobuvirus, Brazil. Virus Genes 2017, 53, 105-110. [CrossRef]

130. Khamrin, P.; Maneekarn, N.; Peerakome, S.; Okitsu, S.; Mizuguchi, M.; Ushijima, H. Bovine kobuviruses from cattle with diarrhea. Emerg. Infect. Dis. 2008, 14, 985-986. [CrossRef] [PubMed]

131. Park, S.J.; Kim, H.K.; Song, D.S.; Moon, H.J.; Park, B.K. Molecular detection and genetic characterization of kobuviruses in fecal samples collected from diarrheic cattle in Korea. Infect. Genet. Evol. 2011, 11, 1178-1182. [CrossRef]

132. Jeoung, H.Y.; Lim, J.A.; Jeong, W.; Oem, J.K.; An, D.J. Three clusters of bovine kobuvirus isolated in Korea, 2008-2010. Virus Genes 2011, 42, 402-406. [CrossRef] [PubMed]

133. Ribeiro, J.; Lorenzetti, E.; Júnior, J.C.R.; da Silva Medeiros, T.N.; Alfieri, A.F.; Alfieri, A.A. Phylogenetic analysis of VP1 and RdRP genes of Brazilian aichivirus B strains involved in a diarrhea outbreak in dairy calves. Arch. Virol. 2017, 162, 3691-3696. [CrossRef] [PubMed]

134. Mohamed, F.F.; Mansour, S.M.G.; Orabi, A.; El-Araby, I.E.; Ng, T.F.F.; Mor, S.K.; Goyal, S.M. Detection and genetic characterization of bovine kobuvirus from calves in Egypt. Arch. Virol. 2018, 163, 1439-1447. [CrossRef]

135. Işidan, H.; Turan, T.; Atasoy, M.O.; Sözdutmaz, I.; Irehan, B. Detection and first molecular characterisation of three picornaviruses from diarrhoeic calves in Turkey. Acta Vet. Hung. 2019, 67, 463-476. [CrossRef] [PubMed] 
136. Savard, C.; Ariel, O.; Fredrickson, R.; Wang, L.; Broes, A. Detection and genome characterization of bovine kobuvirus (BKV) in fecal samples from diarrheic calves in Quebec, Canada. Transbound. Emerg. Dis. 2021. [CrossRef] [PubMed]

137. Moreira, A.S.; Raabis, S.M.; Graham, M.E.; Dreyfus, J.M.; Sibley, S.D.; Godhardt-Cooper, J.A.; Toohey-Kurth, K.L.; Goldberg, T.L.; Peek, S.F. Identification by next-generation sequencing of Aichivirus B in a calf with enterocolitis and neurologic signs. J. Vet. Diagn. Investig. 2017, 29, 208-211. [CrossRef]

138. Abinanti, F.R.; Warfield, M.S. Recovery of a hemadsorbing virus (HADEN) from the gastrointestinal tract of calves. Virology 1961, 14, 288-289. [CrossRef]

139. Spahn, G.J.; Smohanty, S.B.; Hetrick, F.M. Characteristics of hemadsorbing enteric (HADEN) virus. Can. J. Microbiol. 1966, 12, 653-661. [CrossRef]

140. Bachmann, P.A. Properties of a Bovine Parvovirus (Brief Report). Zbl. Vet. Med. B 1971, 18, 80-85. [CrossRef]

141. Manteufel, J.; Truyen, U. Animal bocaviruses: A brief review. Intervirology 2008, 51, 328-334. [CrossRef]

142. Kailasan, S.; Halder, S.; Gurda, B.; Bladek, H.; Chipman, P.R.; McKenna, R.; Brown, K.; Agbandje-McKenna, M. Structure of an enteric pathogen, bovine parvovirus. J. Virol. 2015, 89, 2603-2614. [CrossRef]

143. Mitra, N.; Cernicchiaro, N.; Torres, S.; Li, F.; Hause, B.M. Metagenomic characterization of the virome associated with bovine respiratory disease in feedlot cattle identified novel viruses and suggests an etiologic role for influenza D virus. J. Gen. Virol. 2016, 97, 1771-1784. [CrossRef]

144. Allander, T.; Emerson, S.U.; Engle, R.E.; Purcell, R.H.; Bukh, J. A virus discovery method incorporating DNase treatment and its application to the identification of two bovine parvovirus species. Proc. Natl. Acad. Sci. USA 2001, 98, 11609-11614. [CrossRef]

145. Inaba, Y.; Kurogi, H.; Omori, T.; Matumoto, M. A new serotype of bovine parvovirus. Jpn. J. Microbiol. 1973, 17, 85-86. [CrossRef] [PubMed]

146. Spahn, G.J.; Mohanty, S.B.; Hetrick, F.M. Experimental infection of calves with hemadsorbing enteric (HADEN) virus. Cornell Vet. 1966, 56, 377-386.

147. Durham, P.J.; Lax, A.; Johnson, R.H. Pathological and virological studies of experimental parvoviral enteritis in calves. Res. Vet. Sci. 1985, 38, 209-219. [CrossRef]

148. McFerran, J.B. Bovine enteroviruses. Ann. N. Y. Acad. Sci. 1962, 101, 436-443. [CrossRef]

149. Gomez, D.E.; Weese, J.S. Viral enteritis in calves. Can. Vet. J. 2017, 58, 1267-1274. [PubMed]

150. Blas-Machado, U.; Saliki, J.T.; Boileau, M.J.; Goens, S.D.; Caseltine, S.L.; Duffy, J.C.; Welsh, R.D. Fatal ulcerative and hemorrhagic typhlocolitis in a pregnant heifer associated with natural bovine enterovirus type-1 infection. Vet. Pathol. 2007, 44, 110-115. [CrossRef] [PubMed]

151. Todd, D.; Martin, S.J. Studies of the replication of a bovine enterovirus RNA. J. Gen. Virol. 1979, 43, 75-89. [CrossRef] [PubMed]

152. Earle, J.A.; Skuce, R.A.; Fleming, C.S.; Hoey, E.M.; Martin, S.J. The complete nucleotide sequence of a bovine enterovirus. J. Gen. Virol. 1988, 69 Pt 2, 253-263. [CrossRef]

153. Sobhy, N.M.; Mor, S.K.; Mohammed, M.E.; Bastawecy, I.M.; Fakhry, H.M.; Youssef, C.R.; Abouzeid, N.Z.; Goyal, S.M. Isolation and molecular characterization of bovine enteroviruses in Egypt. Vet. J. 2015, 206, 317-321. [CrossRef] [PubMed]

154. Tsuchiaka, S.; Rahpaya, S.S.; Otomaru, K.; Aoki, H.; Kishimoto, M.; Naoi, Y.; Omatsu, T.; Sano, K.; Okazaki-Terashima, S.; Katayama, Y.; et al. Identification of a novel bovine enterovirus possessing highly divergent amino acid sequences in capsid protein. BMC Microbiol. 2017, 17, 18. [CrossRef]

155. Zell, R.; Krumbholz, A.; Dauber, M.; Hoey, E.; Wutzler, P. Molecular-based reclassification of the bovine enteroviruses. J. Gen. Virol. 2006, 87 Pt 2, 375-385. [CrossRef]

156. Knowles, N.J.; Barnett, I.T. A serological classification of bovine enteroviruses. Arch. Virol. 1985, 83, 141-155. [CrossRef] [PubMed]

157. Blas-Machado, U.; Saliki, J.T.; Sánchez, S.; Brown, C.C.; Zhang, J.; Keys, D.; Woolums, A.; Harvey, S.B. Pathogenesis of a bovine enterovirus-1 isolate in experimentally infected calves. Vet. Pathol. 2011, 48, 1075-1084. [CrossRef] [PubMed]

158. Hoffmann, B.; Scheuch, M.; Höper, D.; Jungblut, R.; Holsteg, M.; Schirrmeier, H.; Eschbaumer, M.; Goller, K.V.; Wernike, K.; Fischer, M.; et al. Novel orthobunyavirus in Cattle, Europe, 2011. Emerg. Infect. Dis. 2012, 18, 469-472. [CrossRef]

159. Wernike, K.; Beer, M. Re-circulation of Schmallenberg virus, Germany, 2019. Transbound. Emerg. Dis. 2020, 67, 2290-2295. [CrossRef]

160. Wernike, K.; Eschbaumer, M.; Breithaupt, A.; Hoffmann, B.; Beer, M. Schmallenberg virus challenge models in cattle: Infectious serum or culture-grown virus? Vet. Res. 2012, 43, 84. [CrossRef]

161. Lechner, I.; Wüthrich, M.; Meylan, M.; van den Borne, B.H.P.; Schüpbach-Regula, G. Association of clinical signs after acute Schmallenberg virus infection with milk production and fertility in Swiss dairy cows. Prev. Vet. Med. 2017, 146, 121-129. [CrossRef] [PubMed]

162. Barreiros, M.A.; Alfieri, A.F.; Médici, K.C.; Leite, J.P.; Alfieri, A.A. G and P genotypes of group A rotavirus from diarrhoeic calves born to cows vaccinated against the NCDV (P[1],G6) rotavirus strain. J. Vet. Med. B Infect. Dis. Vet. Public Health 2004, 51, 104-109. [CrossRef] [PubMed]

163. Da Silva Medeiros, T.N.; Lorenzetti, E.; Alfieri, A.F.; Alfieri, A.A. Phylogenetic analysis of a G6P[5] bovine rotavirus strain isolated in a neonatal diarrhea outbreak in a beef cattle herd vaccinated with G6P[1] and G10P[11] genotypes. Arch. Virol. 2015, 160, 447-451. [CrossRef] [PubMed]

164. Karayel, I.; Fehér, E.; Marton, S.; Coskun, N.; Bányai, K.; Alkan, F. Putative vaccine breakthrough event associated with heterotypic rotavirus infection in newborn calves, Turkey, 2015. Vet. Microbiol. 2017, 201, 7-13. [CrossRef] 
165. Gonzalez, D.D.; Mozgovoj, M.V.; Bellido, D.; Rodriguez, D.V.; Fernandez, F.M.; Wigdorovitz, A.; Parreño, V.G.; Dus Santos, M.J. Evaluation of a bovine rotavirus VP6 vaccine efficacy in the calf model of infection and disease. Vet. Immunol. Immunopathol. 2010, 15, 155-160. [CrossRef]

166. Ikemori, Y.; Ohta, M.; Umeda, K.; Icatlo, F.C., Jr.; Kuroki, M.; Yokoyama, H.; Kodama, Y. Passive protection of neonatal calves against bovine coronavirus-induced diarrhea by administration of egg yolk or colostrum antibody powder. Vet. Microbiol. 1997, 58, 105-111. [CrossRef]

167. Vega, C.; Bok, M.; Chacana, P.; Saif, L.; Fernandez, F.; Parreño, V. Egg yolk IgY: Protection against rotavirus induced diarrhea and modulatory effect on the systemic and mucosal antibody responses in newborn calves. Vet. Immunol. Immunopathol. 2011, 15, 156-169. [CrossRef]

168. Vega, C.G.; Bok, M.; Ebinger, M.; Rocha, L.A.; Rivolta, A.A.; González Thomas, V.; Muntadas, P.; D’Aloia, R.; Pinto, V.; Parreño, V.; et al. A new passive immune strategy based on IgY antibodies as a key element to control neonatal calf diarrhea in dairy farms. BMC Vet. Res. 2020, 29, 264. [CrossRef]

169. Vlasova, A.N.; Saif, L.J. Bovine Coronavirus and the Associated Diseases. Front. Vet. Sci. 2021, 31, 643220. [CrossRef]

170. Lee, M.H.; Jeoung, H.Y.; Lim, J.A.; Song, J.Y.; Song, D.S.; An, D.J. Kobuvirus in South Korean black goats. Virus Genes 2012, 45, 186-189. [CrossRef]

171. Braun, U.; Hilbe, M.; Peterhans, E.; Schweizer, M. Border disease in cattle. Vet. J. 2019, 246, 12-20. [CrossRef] [PubMed]

172. Gür, S.; Yapkiç, O.; Yilmaz, A. Serological survey of bovine enterovirus type 1 in different mammalian species in Turkey. Zoonoses Public Health 2008, 55, 106-111. [CrossRef] [PubMed]

173. Gür, S.; Gürçay, M.; Seyrek, A. A study regarding bovine enterovirus type 1 infection in domestic animals and humans: An evaluation from the zoonotic aspect. J. Vet. Med. Sci. 2019, 26, 1824-1828. [CrossRef] [PubMed]

174. Vijgen, L.; Keyaerts, E.; Moës, E.; Thoelen, I.; Wollants, E.; Lemey, P.; Vandamme, A.M.; Van Ranst, M. Complete genomic sequence of human coronavirus OC43: Molecular clock analysis suggests a relatively recent zoonotic coronavirus transmission event. J. Virol. 2005, 79, 1595-15604. [CrossRef]

175. Cho, E.H.; Soliman, M.; Alfajaro, M.M.; Kim, J.Y.; Seo, J.Y.; Park, J.G.; Kim, D.S.; Baek, Y.B.; Kang, M.I.; Park, S.I.; et al. Bovine Nebovirus Interacts with a Wide Spectrum of Histo-Blood Group Antigens. J. Virol. 2018, 13, e02160-17. [CrossRef]

176. Mauroy, A.; Scipioni, A.; Mathijs, E.; Ziant, D.; Daube, G.; Thiry, E. Genetic and evolutionary perspectives on genogroup III, genotype 2 bovine noroviruses. Arch. Virol. 2014, 159, 39-49. [CrossRef]

177. Castells, M.; Cristina, J.; Colina, R. Evolutionary history and spatiotemporal dynamic of GIII norovirus: From emergence to classification in four genotypes. Transbound. Emerg. Dis. 2021. [CrossRef]

178. Hamada, N.; Masunaga, K.; Ohtsu, Y.; Kato, H.; Tsuji, K.; Maeda, H.; Shingu, M.; Toyoda, T. Nucleotide sequence of the gene encoding the RNA polymerase and the $3^{\prime}$ non-coding region of a bovine enterovirus Japanese isolate: Rapid synonymous substitutions between European and Japanese strains. Arch. Virol. 1998, 143, 815-821. [CrossRef] [PubMed]

179. Padhi, A.; Ma, L. Time-dependent selection pressure on two arthropod-borne RNA viruses in the same serogroup. Infect. Genet. Evol. 2015, 32, 255-264. [CrossRef]

180. Smits, S.L.; Lavazza, A.; Matiz, K.; Horzinek, M.C.; Koopmans, M.P.; de Groot, R.J. Phylogenetic and evolutionary relationships among torovirus field variants: Evidence for multiple intertypic recombination events. J. Virol. 2003, 77, 9567-9577. [CrossRef]

181. Luzzago, C.; Ebranati, E.; Sassera, D.; Lo Presti, A.; Lauzi, S.; Gabanelli, E.; Ciccozzi, M.; Zehender, G. Spatial and temporal reconstruction of bovine viral diarrhea virus genotype 1 dispersion in Italy. Infect. Genet. Evol. 2012, 12, 324-331. [CrossRef]

182. Chernick, A.; Godson, D.L.; van der Meer, F. Metadata beyond the sequence enables the phylodynamic inference of bovine viral diarrhea virus type 1a isolates from Western Canada. Infect. Genet. Evol. 2014, 28, 367-374. [CrossRef]

183. Martínez, N.; Brandão, P.E.; de Souza, S.P.; Barrera, M.; Santana, N.; de Arce, H.D.; Pérez, L.J. Molecular and phylogenetic analysis of bovine coronavirus based on the spike glycoprotein gene. Infect. Genet. Evol. 2012, 12, 1870-1878. [CrossRef]

184. Keha, A.; Xue, L.; Yan, S.; Yue, H.; Tang, C. Prevalence of a novel bovine coronavirus strain with a recombinant hemagglutinin/esterase gene in dairy calves in China. Transbound. Emerg. Dis. 2019, 66, 1971-1981. [CrossRef] [PubMed]

185. Colina, S.E.; Serena, M.S.; Echeverría, M.G.; Metz, G.E. Clinical and molecular aspects of veterinary coronaviruses. Virus Res. 2021, 297, 198382. [CrossRef] [PubMed]

186. Li, M.; Yang, J.; Yu, T.F. Identification of a recombinant isolate of ungulate copiparvovirus. Virus Genes 2018, 54, 596-598. [CrossRef] [PubMed]

187. Weber, M.N.; Streck, A.F.; Silveira, S.; Mósena, A.C.S.; da Silva, M.S.; Canal, C.W. Homologous recombination in pestiviruses: Identification of three putative novel events between different subtypes/genogroups. Infect. Genet. Evol. 2015, 30, 219-224. [CrossRef]

188. Goller, K.V.; Höper, D.; Schirrmeier, H.; Mettenleiter, T.C.; Beer, M. Schmallenberg virus as possible ancestor of Shamonda virus. Emerg. Infect. Dis. 2012, 18, 1644-1646. [CrossRef] 